\title{
Innovative substance 2250 as a highly promising anti-neoplastic agent in malignant pancreatic carcinoma - in vitro and in vivo
}

M. Buchholz ${ }^{1 *}$, B. Majchrzak-Stiller ${ }^{1}$, S. Hahn², D. Vangala²,4, R. W. Pfirrmann³ ${ }^{3}$ W. Uhl' ${ }^{1}$, C. Braumann ${ }^{1}$ and A. M. Chromik'

\begin{abstract}
Background: Former studies already revealed the anti-neoplastic properties of the anti-infective agent Taurolidine (TRD) against many tumor species in vitro and in vivo. Its anti-proliferative and cell death inducing capacity is largely due to its main derivative Taurultam (TRLT). In this study it could be demonstrated, that substance 2250 - a newly defined innovative structural analogue of TRLT - exhibits an anti-neoplastic effect on malignant pancreatic carcinoma in vitro and in vivo.

Methods: The anti-neoplastic potential of substance 2250 as well as its mode of action was demonstrated in extensive in vitro analysis, followed by successful and effective in vivo testings, using xenograft models derived from established pancreatic cancer cell lines as well as patient derived tissue.

Results: Our functional analysis regarding the role of oxidative stress (ROS) and caspase activated apoptosis showed, that ROS driven programmed cell death (PCD) is the major mechanisms induced by substance 2250 in pancreatic carcinoma. What is strongly relevant towards clinical practice is especially the observed inhibition of patient derived pancreatic cancer tumor growth in mice treated with this new substance in combination with its sharply higher metabolic stability.
\end{abstract}

Conclusion: These encouraging results provide new therapeutical opportunities in pancreatic cancer treatment and build the basis for further functional analysis as well as first clinical studies for this promising agent.

Keywords: Taurolidine, Apoptosis, Chemotherapy, Cancer, Substance 2250

\section{Background}

Pancreatic ductal adenocarcinoma (PDAC) is the most lethal common cancer, usually diagnosed at an advanced stage when curative therapy is almost impossible [1]. It is the fourth most common cause of cancer-related death in Europe [2] and in the US [3]. The pancreatic adenocarcinoma typically has a poor prognosis with a five year relative survival rate of 4-5\% [4]. In fact, incidence and mortality of PDAC are almost equal. Surgical resection is the only

\footnotetext{
* Correspondence: marie.buchholz-a7y@rub.de

${ }^{1}$ Division of Molecular and Clinical Research, St. Josef-Hospital, Ruhr-University Bochum, Bochum, Germany

Full list of author information is available at the end of the article
}

potentially curative therapy for pancreatic cancer. Because of the poor outcome associated with surgery only, the role of adjuvant therapies has been extensively evaluated. A series of studies revealed, that chemotherapy with gemcitabine or fluorouracil improves the overall survival of patients with pancreatic adenocarcinoma [5-8]. In the majority of cases a complete resection of the tumor is impossible. Therefore a palliative chemotherapy may be conducted to prolong survival and improve the quality of life. In these cases new combination therapies like FOLFIRINOX are investigated in clinical trials or are in use [7, 8] However, current chemotherapeutic agents are still disappointing due to their poor response 
and high toxicity. New and innovative agents have to be found to expand the therapeutic opportunities.

Taurolidine (TRD) is a substance derived from the aminosulfonacid taurine. Owing to its anti-inflammatory and its anti-microbial qualities, it has been clinically used primarily in peritonitis and catheter related blood stream infections [9]. 1997 Jacobi et al. could show for the first time, that TRD also applied an anti-proliferative and anti-neoplastic activity in vitro and in vivo [10]. This anti-neoplastic and apoptosis inducing effect could also be verified by other research groups [11] in a variety of cell lines derived from malignant tumors e.g. glioblastoma [12], melanoma [13], mesothelioma [14] and colon carcinoma [15]. Furthermore, latest reports about the systemic application of TRD in patients with gastric carcinoma and glioblastoma revealed promising results with almost absence of toxicity [16, 17].

The favorable safety profile of TRD renders this compound to a promising novel agent for the oncological care. However, the metabolic stability of TRD is limited due to its short half-life [18].

This study was designed to analyze a novel compound related to Taurultam (TRLT), the main derivative of TRD. Substance 2250 is a structural analogue of TRLT and is an oxathiazine derivative (Fig. 1). The respective Sulfonamides are promising substances due to their antibacterial and anti-neoplastic activity. The 1.4.5-Oxathiazin derivatives, like the new substance 2250, are almost unexplored whereas 1.2.3-Oxathiazin derivatives are already identified, mainly as artificial sweeteners [19]. However, no representative studies are published analyzing the anti-neoplastic effects of the substance 2250 so far. The aim of this study was to investigate the anti-neoplastic activity on malignant pancreatic cancer in vitro and in vivo.

\section{Methods}

\section{Cell lines and culture conditions}

Six different human pancreatic cancer cell lines were used for our experiments: AsPC-1 (CLS Cell Lines Service,

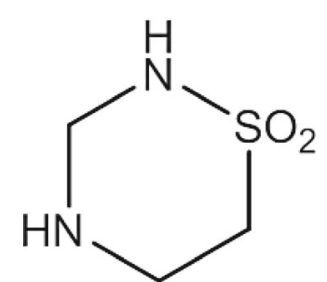

Taurultam

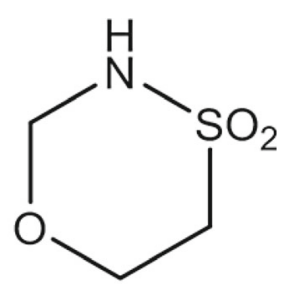

Substance 2250
Fig. 1 Molecular structure of substances TRLT and 2250. Substance 2250, 1.4.5-oxathiazan-dioxid-4.4, is an oxathiazine derivative like TRLT with a moleculare weight of $137.15 \mathrm{~g} / \mathrm{mol}$
Eppenheim, Germany), BxPC-3 (ATCC - LGC Standards GmbH, Wesel, Germany), MiaPaca-2 (ATCC - LGC Standards GmbH, Wesel, Germany), Panc-1 (CLS Cell Lines Service, Eppenheim, Germany) and Panc-TuI (ATCC - LGC Standards GmbH, Wesel, Germany). Cells were passaged fewer than 6 months after receiving from the mentioned cell banks. Authentication was analyzed by STR analysis. MiaPaca-2, Panc-1 and Panc-TuI cells were cultured in Dulbecco's Modified Eagle Medium (DMEM). The remaining cell lines (AsPC-1, BxPC-3) were maintained in RPMI 1640. All cultures were supplemented with the antibiotics penicillin $(100 \mathrm{U} / \mathrm{ml})$, streptomycin $(100 \mathrm{U} / \mathrm{ml})$ and $2 \mathrm{mM}$ L-Glutamine. AsPC-1 cells were further supplemented with $1 \mathrm{mM}$ Sodium Pyruvate. Cells were grown as monolayer and cultured in $25 \mathrm{~cm}^{2}$ flasks at $37{ }^{\circ} \mathrm{C}$ and $5 \% \mathrm{CO}_{2}$ in humidified atmosphere.

\section{Tissue}

Different human pancreatic cancer tissues were used for the in vivo experiments:

Bo70, adenocarcinoma, UICC IIb.

Bo 80, adenocarcinoma, UICC IIb.

\section{Reagents}

The 2250 and TRLT ultrapure powder (kindly provided by Geistlich Pharma AG, Wohlhusen, Switzerland) was dissolved in double distilled Water $\left(\mathrm{ddH}_{2} \mathrm{O}\right)$, sterile filtered, set to a physiological $\mathrm{pH}$ and freshly prepared once per week.

\section{MTT cytotoxicity assay}

Cells were seeded to a density of $3.5 \times 10^{4}$ cells/well in 96-well plates and incubated for $24 \mathrm{~h}$ to obtain a sub confluent monolayer. To examine the dose-response of 2250 and TRLT regarding its anti-neoplastic activity, cells were incubated with increasing concentrations $(100,200,500$, $1000,1500,2000 \mu \mathrm{mol} / \mathrm{l}$ ) and $\mathrm{ddH}_{2} \mathrm{O}$ as control for 6,12 , 24 and $48 \mathrm{~h} .4 \mathrm{~h}$ before the measurement $10 \mu \mathrm{l}$ yellow MTT (3-(4,5-Dimethylthiazol-2-yl)-2,5-diphenyltetrazoliumbromid) reagent $(5 \mathrm{mg} / \mathrm{ml}$ ) was added to the test media. Yellow MTT is converted by viable cells into violet Formazan crystals. The test media was discarded and $50 \mu \mathrm{l}$ DMSO (Dimethylsulfoxide) was applied. After an incubation time of 5-10 min the viability of cells could be analyzed by using a microplate absorbance reader by measuring the OD (optical density) (Tecan trading AG, Switzerland). The amount of violet Formazan is directly proportional to the amount of viable cells. The assay was performed in 4-6 independent experiments with consecutive passages.

\section{BrdU proliferation assay}

Cells were seeded to a density of $4 \times 10^{4}$ cells/well in 96-well plates and incubated for $24 \mathrm{~h}$ to obtain a sub 
confluent monolayer. To examine the dose-response of 2250 and TRLT regarding its anti-proliferative activity, cells were incubated with increasing concentrations of $2250(100,200,500,1000,1500,2000 \mu \mathrm{mol} / \mathrm{l})$ and $\mathrm{ddH}_{2} \mathrm{O}$ as control for $6 \mathrm{~h}$ and submitted to BrdU proliferation assay (5-bromo-2-deoxyuridine)-ELISA (Roche Applied Science, Mannheim, Germany) according to the manufacturer's instructions. Based on the incorporation of the thymidine analogue BrdU during DNA synthesis, the amount of synthesized DNA is detected using a microplate absorbance reader (Tecan trading AG, Switzerland). BrdU assays were performed with 8 replicates of three independent experiments with consecutive passages. The incubation time of $6 \mathrm{~h}$ has been shown to be appropriate for the BrdU proliferation assay in previous experiments.

\section{Flow Cytometry analysis}

Cells were seeded to a density of $2 \times 10^{5}$ cells/well in 6 well plates and incubated for $24 \mathrm{~h}$ to obtain a subconfluent monolayer. Different concentrations of 2250 $(200,500,1000,1500,2000 \mu \mathrm{mol} / \mathrm{l})$ and $\mathrm{ddH}_{2} \mathrm{O}$ as control were used for $24 \mathrm{~h}$ and $48 \mathrm{~h}$ before analyzed by FACS analysis. FACS analysis was performed in 4-6 independent experiments with 2-4 consecutive passages. Cells were fixed in $200 \mu \mathrm{l}$ binding buffer (Bender MedSystems, Vienna, Austria). Subsequently, 5-10 $\mu \mathrm{l}$ Annexin V-FITC (BD Biosciences, Heidelberg, Germany) was added to the cell suspension and incubated for $15 \mathrm{~min}$ at room temperature in the dark. Thereafter, $10 \mu$ Propidiumiodide (PI) (Bender MedSystems, Vienna, Austria) was added. Cells were analyzed immediately using a flow cytometer (FACS Calibur BD Biosciences, Heidelberg, Germany) for Annexin V-FITC (apoptotic) and PI (necrotic) binding. Dot plots and histograms were analyzed by CellQuest Pro software (BD Biosciences, Heidelberg, Germany).

\section{Functional mechanisms}

To get insights into functional mechanisms of drug effects cells were additionally treated with the radical scavenger $\mathrm{N}$-acetylcysteine NAC (5 mmol/l) (Sigma Aldrich, Munich, Germany) or the pan caspase inhibitor-zVad ( $2 \mu \mathrm{mol} / \mathrm{l})$ (Enzo Life Sciences, Lörrach, Germany) before analysis by FACS or MTT standard procedure as already described. Concentrations of 500 and $1000 \mu \mathrm{mol} / \mathrm{l}$ 2250 with an incubation time of $24 \mathrm{~h}$ were used for co-incubation assays in all cell lines.

The direct impact of 2250 on the cellular level of reactive oxygen species (ROS) was analyzed using the Cellular ROS/ Superoxide Detection Assay KIT (Abcam, Cambridge, UK) following the manufactures instructions.

\section{Analysis of the maximal tolerable dose Acute toxicity}

For determining the acute toxicity of substance 2250 in nude mice, mice (each group $n=8-10$ ) were treated intraperitoneal (ip) with different concentrations (500, $1000,1500,2000 \mathrm{mg} / \mathrm{kg}^{*} \mathrm{BW}$ ) once, followed by control of body weight and general vital function. A loss of $20 \%$ of body weight over $48 \mathrm{~h}$ was classified as toxic.

\section{Chronic toxicity}

To assess the chronic toxicity mice were treated with different concentrations of substance 2250 (500, 1000, $\left.1500 \mathrm{mg} / \mathrm{kg}^{*} \mathrm{BW}\right)$ on alternating days for 3 weeks. Control of body weight and general vital function were measured as well. A loss of $20 \%$ of body weight over $48 \mathrm{~h}$ was classified as toxic.

\section{Analysis of metabolic half-life in blood}

For determining the metabolic half-life of the new substance 2250 in the blood of nude mice, a colorimetric assay using NASH-Reagent and protein free serum was used. The serum level was analyzed $1 \mathrm{~h}$ and $25 \mathrm{~h}$ after treatment with the substance $2250\left(500 \mathrm{mg} / \mathrm{kg}^{*} \mathrm{BW}\right)$.

\section{Animal studies}

Five-week-old female NMRI Foxn1nu/Foxn1nu mice (Janvier, France) were acclimated into a 12-h light cycle-controlled environment 1 week before initiation of the study. The animals were allowed standard laboratory food and water ad libitum. Mice were anesthetized by inhalation of Isofluran. $5 \times 10^{6}$ cells of different pancreatic adenocarcinoma cell lines (MiaPaca-2 and PancTU-I) or tumor tissue fragments were administered subcutaneously in the flank region. After implantation, the recipient mice were monitored for general health status and the presence of subcutaneous tumors. Tumor volume was determined by measuring tumor diameters (measurement of 2 perpendicular axes of tumor) using a caliper and calculated as.

$$
V=\frac{1}{2}\left(a b^{2}\right),
$$

( $\mathrm{a}=$ larger axe, $\mathrm{b}=$ smaller axe).

Following randomization (two groups, $n=10$ ) the systemic influence of 2250 on tumor growth after intraperitoneal (ip) application were investigated. As the metabolic half-life of 2250 in nude mice was found to be $13.8 \mathrm{~h}$, a dosing schedule of every second day was chosen for the in vivo experiments. Group1: substance $2250500 \mathrm{mg} / \mathrm{kg}^{*} \mathrm{BW}$ on alternating days, group 2: control group Ringer's solution $300 \mu \mathrm{l}$ was applied ip on alternating days. The treatment was initiated when the tumor volume reached 
$200 \mathrm{~mm}^{3}$ and the tumor volume was measured every second day for 2-3 weeks. The experiment was terminated either after an application period of 3 weeks or when the tumor reached a volume of $1000 \mathrm{~mm}^{3}$.

\section{Statistics and calculations}

Results of FACS-analysis (percentage of viable, apoptotic and necrotic cells) as well as results of MTT and BrdU assay (percentage of living/proliferating cells) are expressed as means \pm SEM. Comparison between experimental groups with normal distribution was performed using one-way ANOVA followed by Tukey's post-hoc test. For categorical data Fisher's exact test used if appropriate. $P$-values $\leq 0.05$ were considered as statistically significant and indicated in the figures as follows: ${ }^{* * *} p \leq 0.001, * *$ $p \leq 0.01, * p \leq 0.05$.

For the calculation of metabolic half-life the following formula was used: $G(x)=G o \times\left(\frac{1}{2}\right)^{\frac{x}{t}}$

$\left(\mathrm{G}(\mathrm{x})=\right.$ serum concentration $(24 \mathrm{~h}), \mathrm{G}_{0}=$ serum concentration $(0 \mathrm{~h}), \mathrm{x}=24 \mathrm{~h}, \mathrm{t}=$ metabolic half-time)

\section{Results}

$\mathbf{2 2 5 0}$ has a cytotoxic effect on all cell lines in a dose dependent manner

To determine the effect of substance 2250 on the cell viability the OD (optical density), MTT tests were conducted. As indicated in Fig. 2, incubation with 2250 in increasing concentrations $(100,200,500,1000,1500,2000 \mu \mathrm{mol} / \mathrm{l})$

\section{a}

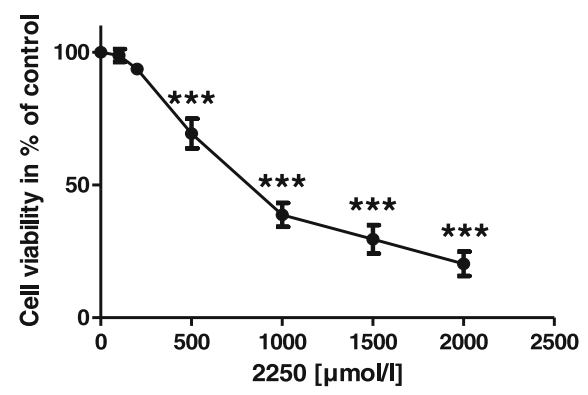

C

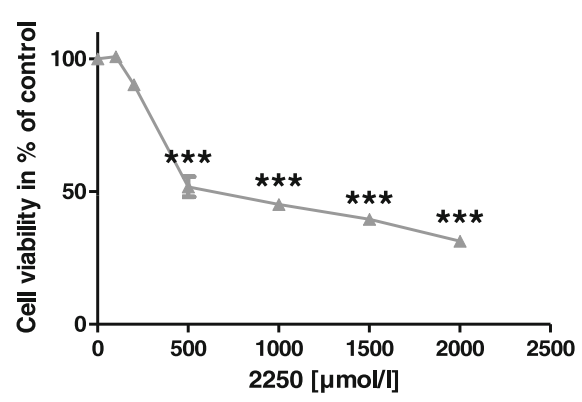

e MTT Panc-Tul 24h

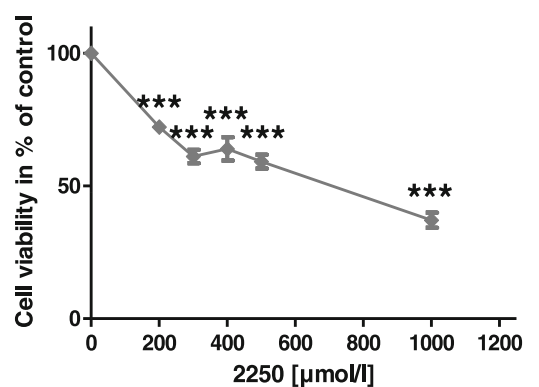

b

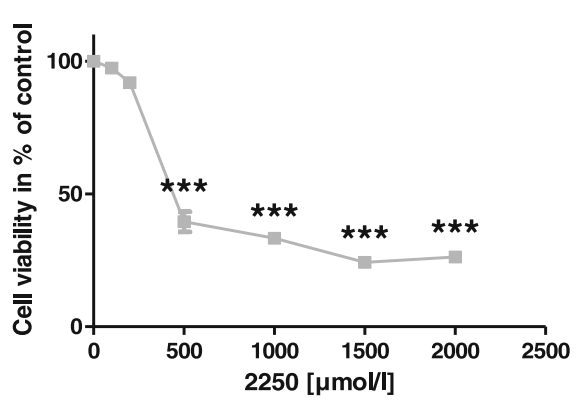

d

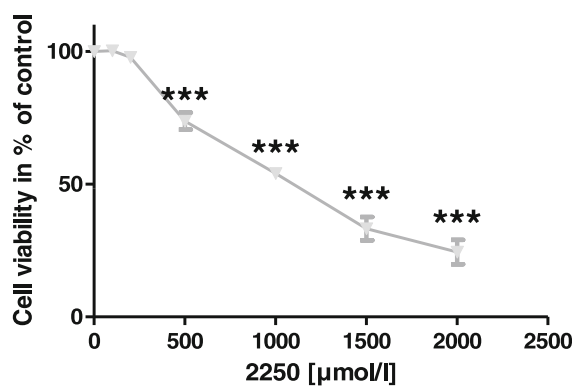

Fig. 2 Effects of 2250 in different malignant cell lines measured by MTT-assay. AsPC-1 (a), BxPC-3 (b), MiaPaca-2 (c), Panc-1 (d) and Panc Tul cells (e) were incubated with 2250 (100, 200, 500, 1000, 1500, $2000 \mu \mathrm{mol} / \mathrm{l})$ and dd $\mathrm{H}_{2} \mathrm{O}$ (control) for $24 \mathrm{~h}$ and submitted to a MTT-assay. Values are means \pm SEM of 6 replicates of three independent experiments with consecutive passages. Asterisk symbols indicate differences between control, which was adjusted to $100 \%$ and 2250 treatment. ${ }^{* *} p \leq 0.001,{ }^{* *} p \leq 0.01,{ }^{*} p \leq 0.05$, n.s. $p>0.05$ (one-way ANOVA followed by Tukey's post-hoc test) 
for $24 \mathrm{~h}$ resulted in a dose dependent reduction of living cells - as measured by MTT assay. The substance 2250 in the cell line Panc-TuI was only analyzed up to a concentration of $1000 \mu \mathrm{mol} / \mathrm{l}$, because this cell line was used additionally for in vivo treatment. The concentrations used in vitro were the important ones for in vivo treatment.

In all cell lines, even the lowest concentration of $500 \mu \mathrm{mol} / \mathrm{l}$ led to a significant reduction of cell viability ranging between $39.4 \%( \pm 3.8 \%)$ (BxPC-3) and $73.8 \%( \pm 3.3 \%)$ (Panc-1) which was significantly lower compared to untreated controls $(100 \%)$ with $\mathrm{ddH}_{2} \mathrm{O}$ (Fig. 2). However, at the following concentration of $1000 \mu \mathrm{mol} / \mathrm{l} 2250$, the monitored reduction of cell viability was more than $50 \%$ in four out of five cell lines. This pronounced reduction, mediated by 2250 in a concentration of $1000 \mu \mathrm{mol} / \mathrm{l}$ resulted in values of living cells between $33.3 \%( \pm 1.2 \%)$ for BxPC-3 and 59.1\% ( $\pm 2.6 \%)$ for PancTuI (Fig. 2b, e). The maximum dose of $2000 \mu \mathrm{mol} / \mathrm{l}$ led to an intense cytotoxic effect in all cell lines. As a result, in three cell lines a proportional doses-effect curve and in BxPC-3 as well as in MiaPaca2 a sigmoid character was observed (Fig. 2). The effective doses (ED) 50 were varying between the different cell lines from $221 \mu \mathrm{mol} / \mathrm{l}$ (BxPC-3) to $1100 \mu \mathrm{mol} / \mathrm{l}$ (Panc-1) within an incubation time of $24 \mathrm{~h}$.

\section{0 inhibits proliferation of all cell lines in a dose dependent manner}

To examine the effect of substance 2250 on cell proliferation in a culture model, BrdU assays were conducted. As indicated in Fig. 3, incubation with substance 2250 in

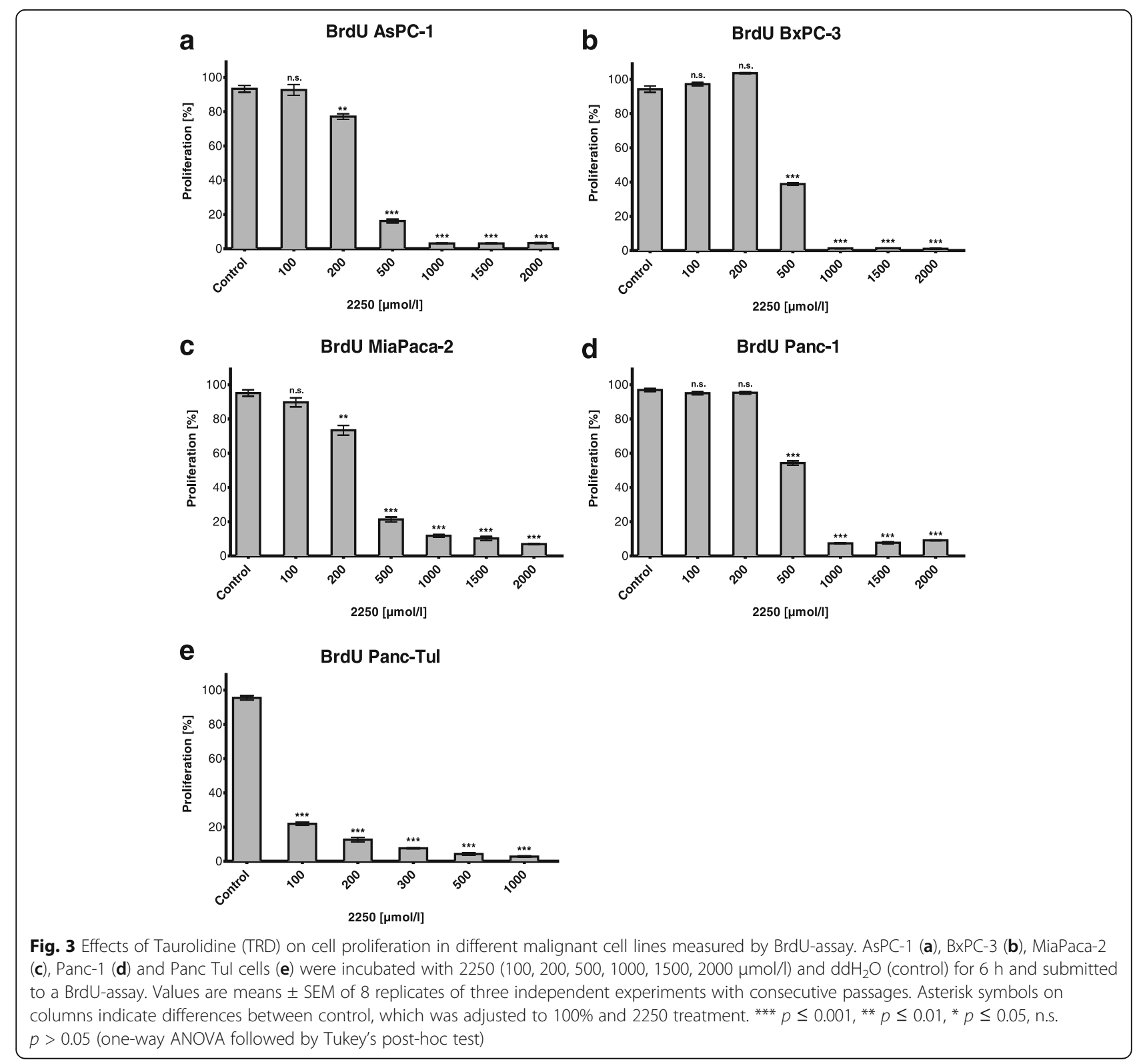


increasing concentrations $(100,200,500,1000,1500$, $2000 \mu \mathrm{mol} / \mathrm{l})$ for $6 \mathrm{~h}$ resulted in a dose dependent reduction of proliferating cells. In three cell lines, even a concentration of $200 \mu \mathrm{mol} / \mathrm{l} 2250$ was capable of inhibiting proliferation leading to values of proliferating cells ranging between $12.7 \%( \pm 1.3 \%)$ (Panc-TuI) and $77.2 \%$ $( \pm 1.6 \%)$ (AsPC-1) which was significantly lower compared to untreated controls (100\%) with $\mathrm{ddH}_{2} \mathrm{O}$ (Fig. 3). The concentration of $500 \mu \mathrm{mol} / \mathrm{l} 2250$ significantly inhibited proliferation in all analyzed cell lines. This inhibition resulted in amounts of proliferating cells between $4.3 \%( \pm 0.6 \%)$ for Panc-TuI and $54.3 \%( \pm 1.2)$ for Panc-1 (Fig. 3 d, e). The maximum dose of $2000 \mu \mathrm{mol} / 1$ implicated an extended inhibition of proliferation in all cell lines, so the dose response for cell proliferation could be characterized as proportional in all five pancreatic cancer cell lines (Fig. 3).

Table 1 shows the relative amounts of cell viability and cell proliferation of three different cell lines upon treatment with substances TRLT and $2250(2000 \mu \mathrm{mol} / \mathrm{l}$ each). In all analyzed cell lines substance 2250 shows a substantial higher impact on cell viability as well as on cell proliferation. In AsPC-1 and Panc-1 substance 2250 is even twice as effective as TRLT.

\section{0 induces apoptotic cell death in all cell lines}

Additional FACS analysis revealed the impact of substance 2250 on apoptotic-, as well as on necrotic cell death. As summarized in Fig. 4, incubation of three cell lines for $24 \mathrm{~h}$ with substance 2250 with a concentration of $1000 \mu \mathrm{mol} / \mathrm{l}$ and $1500 \mu \mathrm{mol} / \mathrm{l}$ resulted in a significant reduction of viable cells compared to control treatment with $\mathrm{ddH}_{2} \mathrm{O}$ as evaluated by FACS analysis with Annexin V-FITC and PI. The significant reduction of cell viability by $1000 \mu \mathrm{mol} / \mathrm{l} 2250$ was paralleled by a significant increase of apoptotic cells in all cell lines (Fig. 4). Cell viability following incubation with $1000 \mu \mathrm{mol} / \mathrm{l}$ was varying between $41.1 \%( \pm 0.7 \%)$ for BxPC-3 and $59.0 \%$ $( \pm 1.9 \%)$ for AsPC-1 cells. The strong impact on cell viability was paralleled by a significant apoptotic effect in all cell lines ranging between $14.2 \%( \pm 1.5 \%)$ apoptotic cells for AsPC- 1 and $35.0 \%( \pm 2.01 \%)$ for Panc-TuI. The contribution of necrosis to the loss of cell viability was smaller. However, a significant increase in necrotic cells between $16.4 \%( \pm 2.5 \%)$ for Panc-TuI and 28.9\% ( $\pm 1.0 \%)$ for BxPC-3 was observed (Fig. 4).
The following incubation with $1500 \mu \mathrm{mol} / \mathrm{l}$ of 2250 showed a pronounced and significant reduction in cell viability between $28.5 \%( \pm 1.5 \%)$ for Panc-TuI and $7.6 \%$ $( \pm 0.8 \%)$ for BxPC-3 cells. This reduction in cell viability was also paralleled by a significant increase of apoptotic cells - but only in two of three cell lines (AsPc-1, PancTuI). In BxPc-3 no significant apoptotic alteration was detected. However, BxPc-3 cells responded towards $1500 \mu \mathrm{mol} / \mathrm{l}$ with a strong necrotic effect $80.6 \%( \pm 1.1 \%)$ which was highest observed among all cell lines and concentrations (Fig. 4).

\section{The radical scavenger $\mathrm{N}$-acetylcysteine (NAC) and pancaspase inhibitor z-VAD show divergent effects on 2250 induced cell death}

To evaluate the contribution of Caspase or reactive oxygen species mediated cell death to the observed effects of substance 2250 co-incubation experiments with substance 2250 and NAC or z-VAD were performed.

In AsPc-1 and Panc-1 cells, co-incubation of 2250 with NAC for $24 \mathrm{~h}$ led to a complete protection towards 2250 induced cell death. NAC entirely abrogated the 2250 induced reduction of viable cells leading to cell viability, equal to untreated controls (Fig. 5a, d). In BxPC-3, MiaPaca-2 and Panc-TuI, the co-incubation of 2250 with NAC was characterized by a strong protection of cell viability. However, there was no complete protection in the amount of viable cells compared to untreated controls. The effect could only be characterized as a partial protection (Fig. 5b, c, e).

Further data of FACS analysis of AsPC-1 co-incubated with 2250 and NAC for 24 h shown in Fig. 5 confirmed previous results. In contrast to the MTT assay, the FACS analysis shows this effect on the different cell populations more in detail. The co-incubation was characterized by a completely protection against the 2250 induced reduction of viable cells leading to a significant increase of viable cells (Fig. 6a). No differences from untreated controls were detected. Together with a small but significant reduction of apoptotic cells under treatment with a concentration of $500 \mu \mathrm{mol} / \mathrm{l} 2250$, a complete reduction of necrotic cells could be achieved under treatment with $1000 \mu \mathrm{mol} / \mathrm{l} 2250$ (Fig. 6b, c). Furthermore the cellular level of ROS is significantly increased in cells treated with substance 2250 . Fig. $5 \mathrm{f}$ provides an exemplary presentation of tested cell lines. This effect can be reversed by additional treatment with NAC.

Table 1 Results of MTT and BrdU assay of substance 2250 compared with TRLT in three different cell lines

\begin{tabular}{|c|c|c|c|c|c|c|}
\hline & \multicolumn{2}{|l|}{ AsPC-1 } & \multicolumn{2}{|l|}{$\mathrm{BxPC}-3$} & \multicolumn{2}{|l|}{ Panc-1 } \\
\hline & TRLT & 2250 & TRLT & 2250 & TRLT & 2250 \\
\hline MTT assay cell viability (\%) & $48.78 \pm 2.8$ & $21.00 \pm 3.8$ & $36.01 \pm 7.3$ & $26.24 \pm 0.3$ & $65.24 \pm 1.5$ & $24.4 \pm 4.6$ \\
\hline BrdU Assay cell proliferation (\%) & $8.5 \pm 0.9$ & $3.34 \pm 0.2$ & $6.66 \pm 0.7$ & $1.0 \pm 0.2$ & $16.32 \pm 1.2$ & $9.14 \pm 0.3$ \\
\hline
\end{tabular}




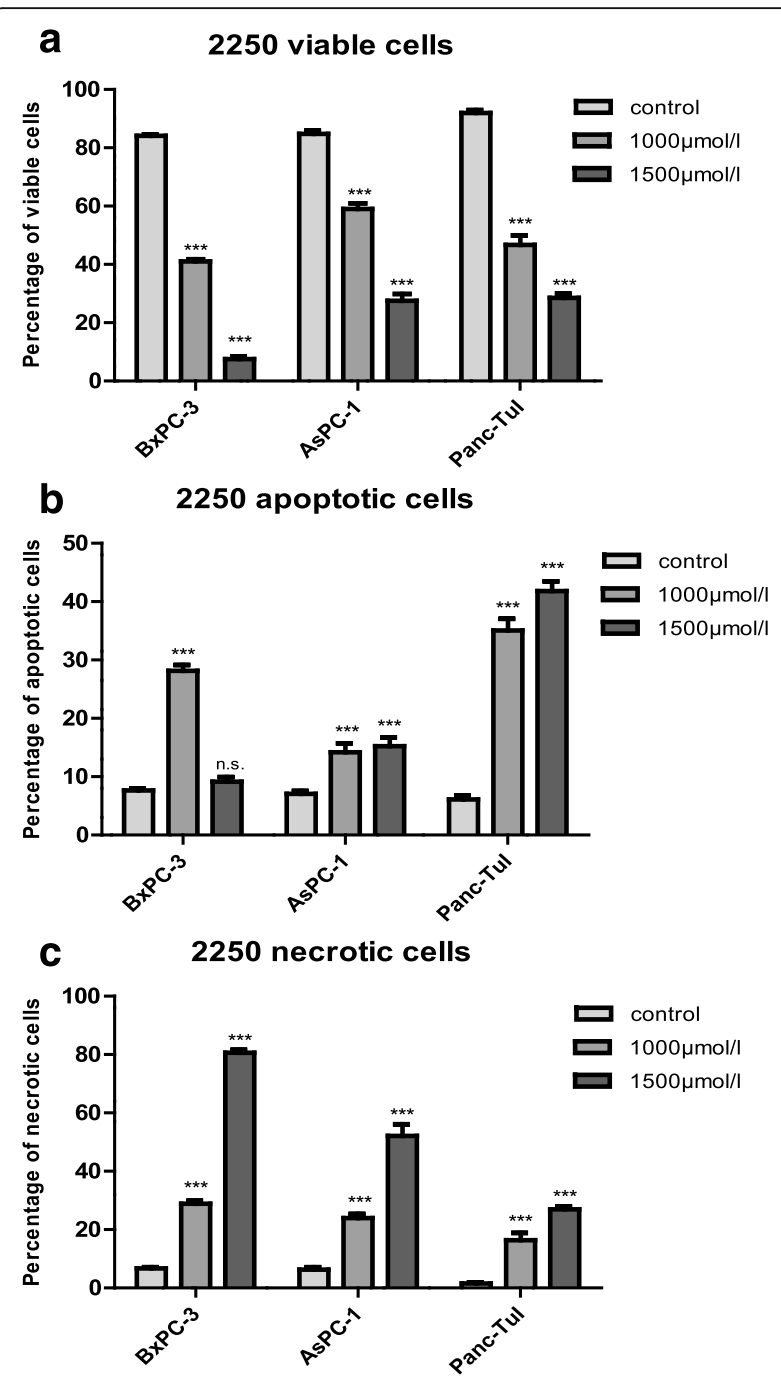

Fig. 4 Effects of $1000 \mu \mathrm{mol} / \mathrm{l}$ and $1500 \mu \mathrm{mol} / \mathrm{l} 2250$ on viability, apoptosis and necrosis in different malignant pancreatic cell lines measured by FACS analysis. AsPC-1 (a), BxPC-3 (b) and Panc-Tul (c) cells were incubated with $2250(1000$ and $1500 \mu \mathrm{mol} / \mathrm{l})$ and $\mathrm{dd}_{2} \mathrm{O}$ (control) for $24 \mathrm{~h}$. The percentages of viable, apoptotic and necrotic cells were determined by FACS-analysis with Annexin V-FITC and Propidiumiodide. Values are means \pm SEM of 4-6 independent experiments with three consecutive passages. Asterisk symbols on columns indicate differences between control and 2250 treatment. ${ }^{* * *} p \leq 0.001,{ }^{* *} p \leq 0.01,{ }^{*} p \leq 0.05$, n.s. $p>0.05$ (one-way ANOVA followed by Tukey's post-hoc test)

All pancreatic cancer cell lines which were analyzed did not show any detectable effect on cell viability after z-VAD co-incubation (data not shown).

Detection of the maximal tolerable dose of substance 2250 By analyzing the acute toxicity, the highest concentration of $2000 \mathrm{mg} / \mathrm{kg}^{*} \mathrm{BW}$ was toxic in nude mice. The body weight was reduced about $1 \mathrm{~g}$ in $48 \mathrm{~h}$ and the mouse died 5 days after treatment. For the other concentrations no changes in body weight and vital function could be observed.
Determining the chronic toxicity it could be observed that concentrations higher than $1000 \mathrm{mg} / \mathrm{kg}^{*} \mathrm{BW}$ are toxic in nude mice. While treatment with $500 \mathrm{mg} /$ $\mathrm{kg}^{*} \mathrm{BW}$ no changes in body weight and vital function could be monitored.

\section{Analysis of metabolic half-life in blood}

For determining the metabolic half-life of the new substance 2250 in blood of nude mice a colorimetric assay using NASH reagent was used. The alignment of the measured values of substance 2250 in mice serum after $1 \mathrm{~h}$ and $25 \mathrm{~h}$ with the calibration curve yielded a metabolic half-life of $13.8 \mathrm{~h}$ (Fig. 7, Table 2).

\section{0 induces reduction of subcutaneous tumor growth in vivo}

Finally, to elucidate the effect of substance 2250 in vivo, we tested the impact of the treatment of xenografts derived from cancer cell lines and patient tissue in different tumor mouse models.

As indicated in Fig. 8, the intraperitoneal (ip) application of $2250\left(500 \mathrm{mg} / \mathrm{kg}^{*} \mathrm{BW}\right)$ reduced the subcutaneous tumor growth in vivo in tumors induced by established pancreatic cancer cell lines (MiaPaca-2, Panc-TuI) as well as in xenograft models from patient tissue. The ip application of 2250 led to a significant reduction of $57 \%$ of relative tumor volume in comparison to the control group after an application period of 3 weeks in tumors caused by the established cell line MiaPaca-2 (Fig. 8a). In a second tumor model evoked by the established cell line Panc-TuI (Fig. 8b) almost the same inhibition of tumor growth was observed by ip application of 2250 (500 mg/ $\left.\mathrm{kg}^{*} \mathrm{BW}\right)$. A significant reduction of $49.7 \%$ of relative tumor growth was detected after an application period of 2 weeks. The tumor volume endpoint of $1000 \mathrm{~mm}^{3}$ was reached after this treatment period and the experiment was terminated. The subcutaneous tumor, derived from patient tissue (Bo 70) was analyzed in a separate tumor model in which a significant reduction of tumor growth of $36.8 \%$ under the treatment with substance 2250 could be observed (Fig. 8c). In a second patient derived xenograft (Bo 80) almost the same inhibition of approximately $30 \%$ could be detected (Fig. 8 d).

\section{Discussion}

The anti-neoplastic effects of the recently developed, novel substance 2250 have not been published yet. During development of the compound, a cytotoxicity test was performed in the glioma cell line LN 229 which indicated a promising anti-neoplastic capacity of the substance 2250 (EC $50=55 \mu \mathrm{g} / \mathrm{ml}$ after $24 \mathrm{~h})$ [unpublished data], similar in potency to TRD. The anti-neoplastic activity of the parent compound TRD 


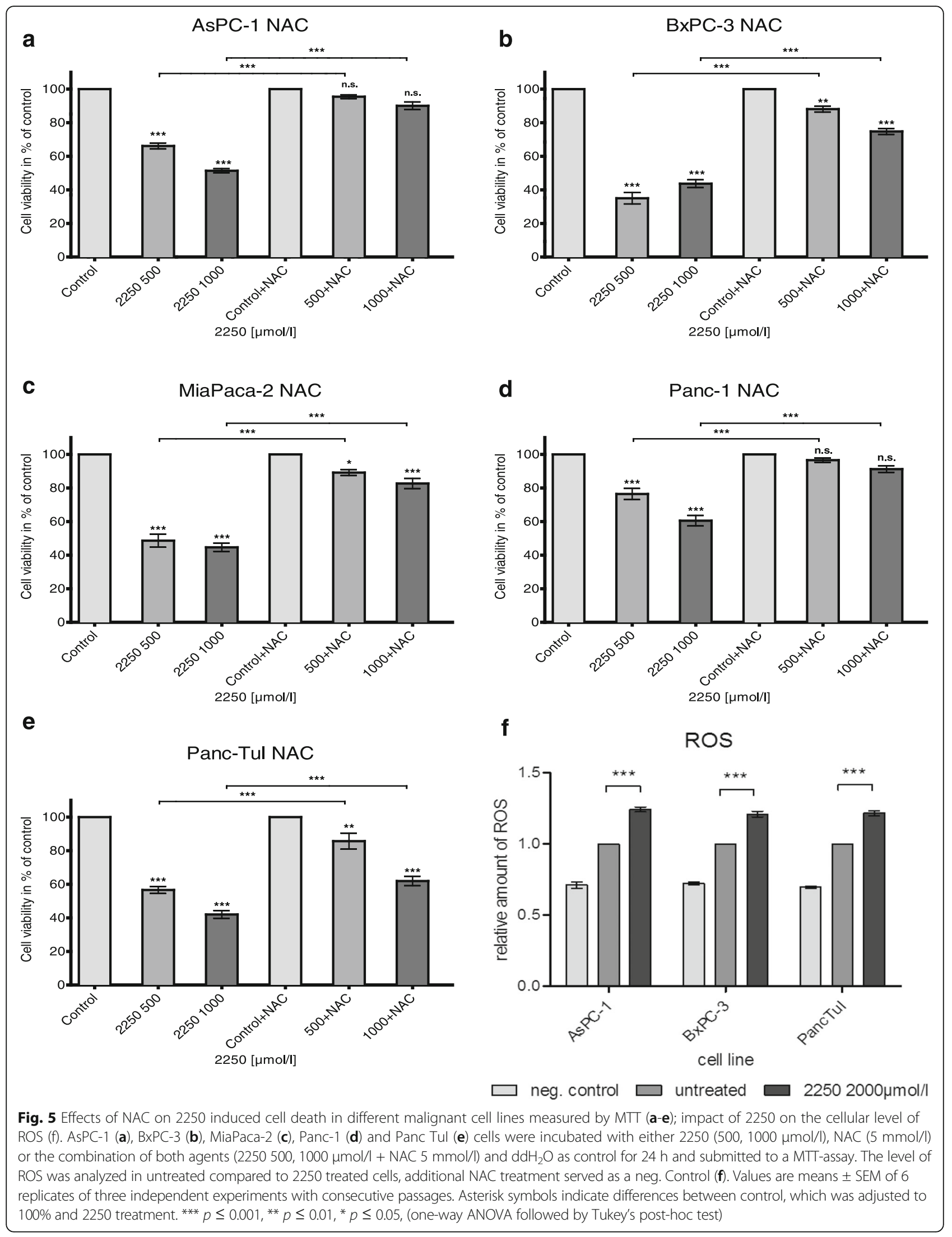



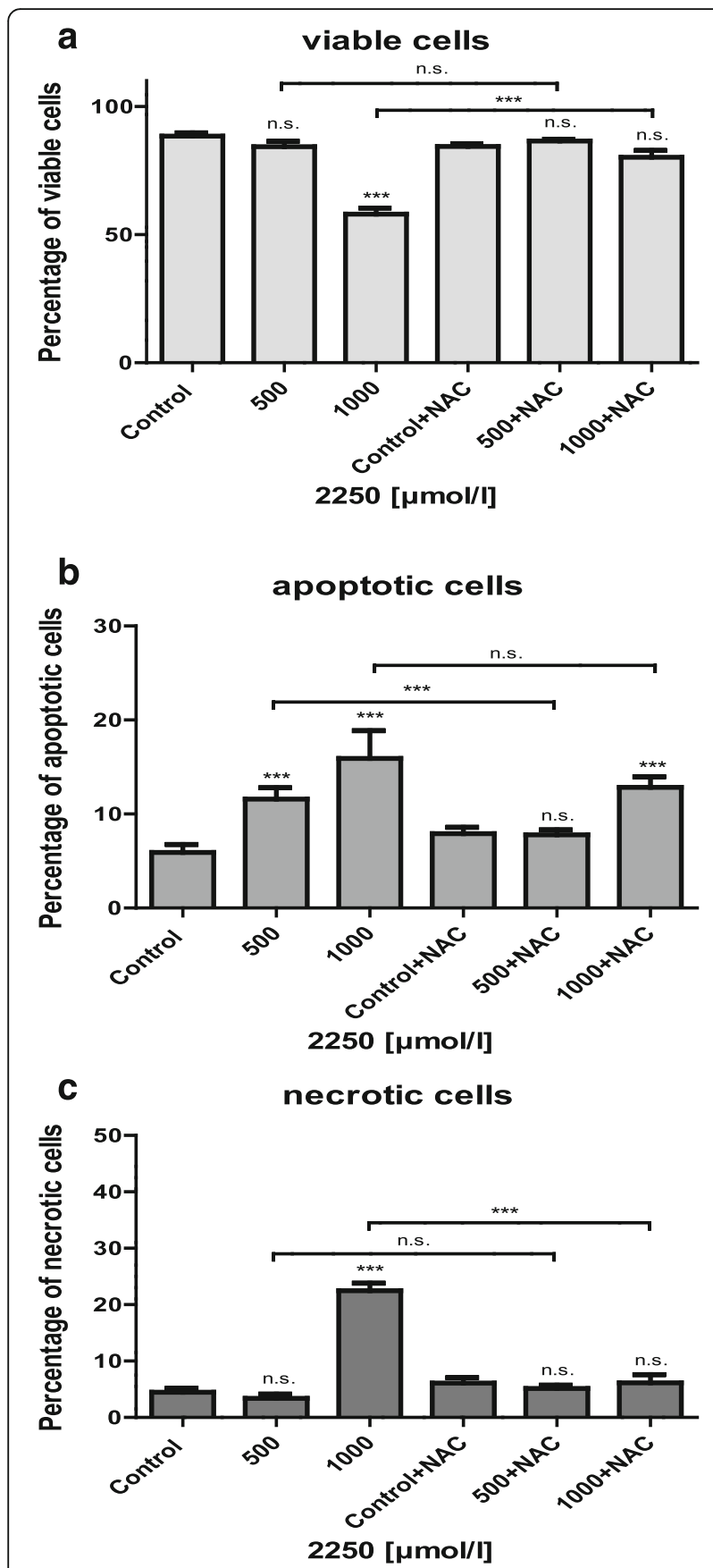

Fig. 6 Effects of NAC on 2250 induced cell death in cell line AsPC1 measured by FACS analysis. AsPC-1 cells were incubated with either $2250(500,1000 \mu \mathrm{mol} / \mathrm{l})$, NAC ( $5 \mathrm{mmol} / \mathrm{l})$ or the combination of both agents (2250 500, $1000 \mu \mathrm{mol} / \mathrm{l}+\mathrm{NAC} 5 \mathrm{mmol} / \mathrm{l})$ and $\mathrm{ddH}_{2} \mathrm{O}$ as control for $24 \mathrm{~h}$. The percentage of viable (a), apoptotic (b) and necrotic (c) cells were determined by FACS analysis. Values are means \pm SEM of 4-6 replicates of three independent experiments with consecutive passages. Asterisk symbols indicate differences between control, which was adjusted to $100 \%$ and 2250 treatment. ${ }^{* * *} p \leq 0.001,{ }^{* *} p \leq 0.01,{ }^{*} p \leq 0.05$, n.s. $p>0.05$ (one-way ANOVA followed by Tukey's post-hoc test) has been demonstrated in many studies on different cancer entities in vitro as well as in vivo $[18,20,21]$ . Even pilot clinical studies confirmed previous results $[16,18,22]$. Therefore, the aim of this study was to analyze anti-neoplastic effects of substance 2250 in comparison to its structural analogue TRLT, the main derivative of its effective parent compound TRD.

In the first part of this study we determined doseresponse characteristics and analyzed the relative contribution of apoptosis and necrosis during substance 2250 induced cell death. In all five different malignant pancreatic cancer cell lines the dose response effects of substance 2250 were nearly homogenous. We found a pattern which is characterized by a proportional or sigmoidal dose effect where increasing concentrations of substance 2250 led to an increase of cell death after 24 and $48 \mathrm{~h}$. This pattern could be observed for the cytotoxicity of the substance via MTT assay, as well as for the anti-proliferative effect by BrdU analysis. This proportional dose effect pattern, observed during this study, is analog to those described in several previous studies for the treatment with TRD [23-26].

Three pancreatic cancer cell lines (AsPC-1, BxPC-3 and PancTuI) also displayed a dose-response relationship concerning the relative distribution of viable, apoptotic and necrotic cells determined by FACS analysis, where the amount of viable cells decreased with increasing concentration of substance 2250 . The incubation with $1000 \mu \mathrm{mol} / \mathrm{l}$ of substance 2250 was characterized by apoptotic as well as necrotic cell death whereby the apoptotic effect was the predominant characteristic. In contrast, the incubation with $1500 \mu \mathrm{mol} / \mathrm{l}$ of substance 2250 was characterized by a pronounced necrotic effect in BxPC-3. This effect became more obvious in AsPC-1. Opposite to this, in PancTuI cells treated with $1500 \mu \mathrm{mol} / \mathrm{l}$ the amount of apoptotic cells prevailed. This dose depending ratio of viable, apoptotic and necrotic cells is according to previous studies with TRD in our group [15] and by others [13, 26]. Regarding the pronounced necrotic effect of rising concentrations of substance 2250, only speculations are possible. Whereby, cell culture models could reveal a potential explanation. Generally, apoptosis is due to caspase-dependent or independent cell destruction and to phagocytosis of the apoptotic cells. In a cell culture setting, which lacks phagocytosis a secondary necrosis follows, which is characterized by the same appearance of primary necrosis [27].

In our in vitro studies there is no possibility of phagocytosis by inflammatory cells, because they are not present in our cell culture model. The marker, used for necrosis (PI) could ultimately not differentiate between a substanceinduced primary necrosis and a secondary necrosis - due to the lack of phagocytosis. Another possible explanation 


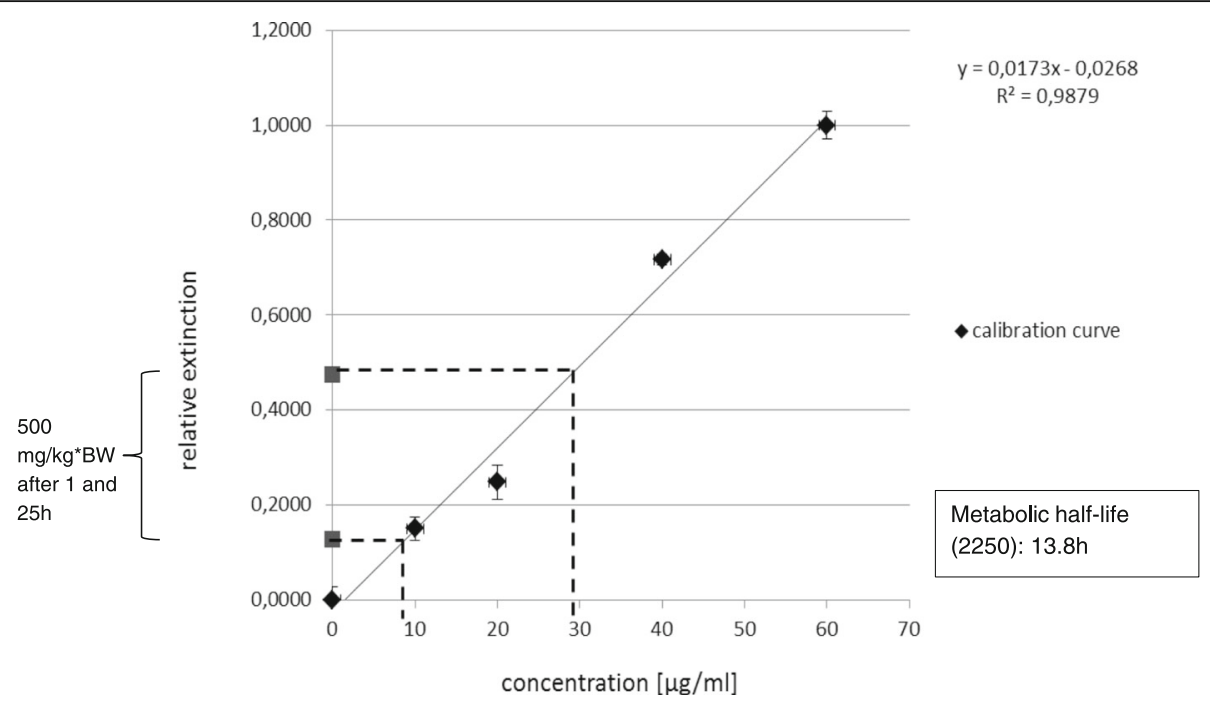

Fig. 7 calibration curve of metabolic half-life measurement. The calibration curve consisting of five different concentrations of substance 2250 served as a standard for the calculation of the metabolic half-life of substance 2250 in nude mice, which resulted in a value of $13.8 \mathrm{~h}$. The according measured parameters are shown in Table 2

might be the induction of a programmed necrosis by substance 2250 itself, as shown previously for Taurolidine [26]. Programmed necrosis is, besides apoptosis and autophagy, the third type of programmed cell death, which involves cell swelling, organelle dysfunction and cell lysis. Programmed necrosis can be induced by different signaling pathways a. o. via activation of death receptors or cell stress can induce activation of receptor- interacting-protein kinases RIP1 and RIP3, which influence mitochondria to induce ROS increase [27, 28]. Further work is required to clarify whether substance 2250 lead to the induction of programmed necrosis on such a high level, at least in BxPC-3 and AsPC- 1 at high concentrations.

The second part of this study deals with the contribution of reactive oxygen species (ROS) to substance 2250 induced cell death and the analysis of another major cell death associated pathway, the caspase pathway. Previous studies with TRD revealed an involvement of ROS 12, 40 [29], triggering apoptosis via caspaseindependent pathways $[12,20]$, caspase-dependent pathways $40[15,20,25]$ as well as necroptosis and autophagy [26]. Furthermore, cell death, induced by ROS, has been shown to be prevented by applying the radical scavenger $\mathrm{N}$-acetycysteine (NAC) [12, 25, 29]. Hence,

Table 2 Measured parameters of metabolic half-life calculation

\begin{tabular}{lll}
\hline $\begin{array}{l}\text { Time of blood } \\
\text { sampling }\end{array}$ & Relative extinction & $\begin{array}{l}\text { Concentration in } \\
\text { serum }[\mu \mathrm{g} / \mathrm{ml}]\end{array}$ \\
\hline $1 \mathrm{~h}$ & 0.475 & 29.044 \\
$25 \mathrm{~h}$ & 0.128 & 8.954 \\
\hline
\end{tabular}

in this study both the cellular ROS induction upon treatment and co-incubation experiments with either the radical scavenger NAC for inhibition of oxidative stress or the pan caspase inhibitor z-VAD for involvement of the caspase pathway were performed. Substance 2250 clearly induced ROS production in all tested cell lines. This effect could be completely canceled by the radical scavenger NAC. In line with this result, all analyzed pancreatic cancer cell lines responded to NAC co-incubation with an attenuated cell death, induced by substance 2250 . Nevertheless, the extent of protection from cell death was divergent between the analyzed cell lines, ranging from partial protection (BxPC-3, MiaPaca-2, PancTuI) to complete protection (AsPC-1, Panc-1). In general, ROS is regarded as being an ambiguous compound in terms of antineoplastic activity [30]. On the one hand, it is able to support tumor cell proliferation and survival $[14,30]$. On the other hand, excessive ROS generation in tumor cells can induce cell death. This therapeutic effect is used by many chemotherapeutics as platinum, arsenic, ascorbate or piperlongumine [13, 30-32]. In conclusion, the generation of ROS and the consequent activation of following pathways is an obvious explanation of the induction of cell death by substance 2250 in pancreatic cancer cell lines. Thus, ROS induced cell death may not be the universal mechanism of substance 2250, but our experiments highlight its central role in programmed cell death (PCD).

We also analyzed another major cell death associated pathway mentioned in the literature referring TRD induced cell death - the caspase pathway [20, 25, 33]. Among the literature, the activation of the caspase 

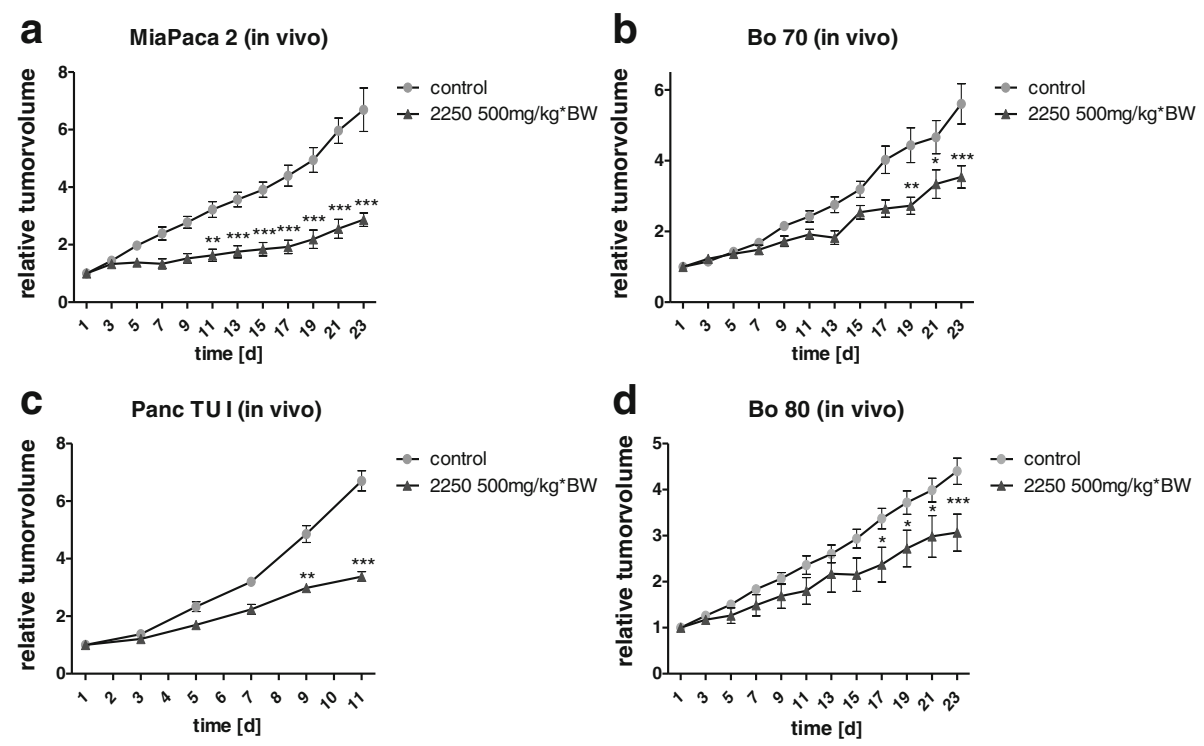

Fig. 8 Effects of $500 \mathrm{mg} / \mathrm{kg}^{*} \mathrm{BW} 2250$ on the subcutaneous tumor growth in nude mice in vivo. Nude mice with tumors of MiaPaca-2 (a), PancTul (c) or patient tissue (b, d) were incubated with $2250\left(500 \mathrm{mg} / \mathrm{kg}^{*} \mathrm{BW}\right)$ and $\mathrm{ddH}_{2} \mathrm{O}$ (control) for up to 3 weeks. The tumor volume was measured on alternating days for up to 3 weeks. Asterisk symbols indicate differences between control and 2250 treatment. ${ }^{* * *} p \leq 0.001$, ${ }^{* *} p \leq 0.01$, ${ }^{*} p \leq 0.05$, n.s. $p>0.05$ (one-way ANOVA followed by Tukey's post-hoc test)

pathway by TRD has been mentioned for several cell lines, but the findings were divergent between different tumor entities. Furthermore, caspase independent PCD induced by TRD was reported in the literature as well $[12,20]$. The analyzed pancreatic cancer cell lines (AsPC-1, BxPC-3) were not protected via inhibition of pan-caspases from PCD induced by substance 2250 in our experiments. Previous studies of our group determined that pancreatic cancer cell lines were not protected from PCD caused by TRD, via inhibition of pan caspases, either [15]. The response observed in pancreatic cancer cell lines regarding the inhibition of 2250 induced cell death, via the pan-caspase inhibitor zVAD, leads to the assumption, that especially for pancreatic cancer cell lines the caspase dependent PCD plays only a minor role. Therefore, other pathways like necroptosis or caspase independent programmed cell death may play a more considerable role. These pathways are well discussed in the latest literature related to cancer therapies [34-37]. Further studies in this field are necessary to clarify the involvement of caspase independent types of programmed cell death following the treatment with the substance 2250 .

On the basis of this foregone promising in vitro results, we analyzed the anti-neoplastic effects of substance 2250 in vivo. Prior to the in vivo studies the metabolic half-life of the new substance 2250 was determined, due to the fact that Taurolidine shows a very short metabolic half-life of only $1-2 \mathrm{~h}$ in healthy human volunteers [22]. Our analysis yielded a metabolic half-life of substance 2250 of $13.8 \mathrm{~h}$ in nude mice, displaying a much higher metabolic stability compared to TRD. Based on the fact that mice have a higher metabolism than humans, it can be assumed, that the metabolic half-life of substance 2250 in humans is even higher. TRD was previously found to suppress tumor growth of different tumor entities in rodents $[10,11,20,21,38-45]$. The ip application of TRD inhibits the ip tumor growth of colonic carcinoma [42], mesothelioma [31], malignant melanoma [13, 45] and pancreatic carcinoma [43, 44]. It could also be shown that the intravenous (iv) application of TRD decreases the ip tumor growth as well [38, 40, 41, 46]. Existing studies also have experiences with the effect of TRD application on subcutaneous tumor growth. In colon carcinoma the subcutaneous tumor growth was not influenced by TRD application [38, 40], whereas the subcutaneous tumor growth in malignant melanoma $[13,47]$ and prostate carcinoma [48] was inhibited by TRD instillation ip and iv.

Therefore our experimental in vivo study was based on the hypothesis that substance 2250 could also inhibit the growth of pancreatic cancer after ip administration in an established cell line model and a xenograft model with patient tissue in nude mice. We observed a significant reduction of subcutaneous tumor growth in tumors induced by established pancreatic cancer cell lines (MiaPaca 2, PancTuI) as well as in xenograft models from patient tissue (Bo70, Bo80). In tumors caused by established pancreatic cell lines, the ip application led to a significant reduction by approximately $50 \%$ of relative tumor volume in comparison to the controls. These results were confirmed by the xenograft 
models derived from patient tissue, where a reduction of relative subcutaneous tumor volume by $30-40 \%$ was observed after treatment with substance 2250 .

\section{Conclusion}

In conclusion, this is the first study providing an evaluation of substance 2250 induced cell death among several pancreatic cancer cell lines in vitro and inhibition of pancreatic tumor growth in vivo. Substance 2250 is characterized by a clear dose response relationship due to the fact that all analyzed cells lines were susceptible to substance 2250 induced cell death. Functional analysis of the involvement of ROS driven and caspase activated PCD showed, that ROS plays a fundamental role inducing cell death in pancreatic carcinoma. In contrast, PCD by caspase activation was less important. Furthermore substance 2250 seems to effectively inhibit pancreatic cancer tumor growth in mice, simultaneously displaying a higher metabolic stability, which will be a strong benefit towards clinical practice. These encouraging results are the basis for further functional analysis and initial clinical studies for this promising agent. It remains to be seen whether 2250 , in analogy to TRD, also exerts anti-inflammatory activity by reducing pro-inflammatory cytokines.

\section{Abbreviations \\ Annexin V-FITC: Annexin V-Fluorescein; BrdU: 5-bromo-2-deoxyuridine; DMEM: Dulbecco's modified eagle medium; DMSO: Dimethylsulfoxide; ELISA: Enzyme Linked Immunosorbent Assay; FACS: Fluoreszcence-activated cell scanning; Ip: Intraperitoneal; NAC: N-acetlycysteine; OD: Optical density; PCD: Programmed cell death; PDAC: Pancreatic ductal adenocarcinoma; PI: Propidiumiodide; ROS: Reactive oxygen species; RPMI 1640: Roswell park memorial institute medium 1640; TRD: Taurolidine; TRLT: Taurultam; UICC: Union international contre le cancer; z-VAD: carbobenzoxy-valyl-alanyl- aspartyl-[O- methyl]- fluoromethylketone}

\section{Acknowledgements}

The substance 2250 was granted by Geistlich, a company in Wolhusen, Switzerland.

\section{Funding}

Our working group has not received any financial support. This study was only financially supported by University Research funding.

\section{Availability of data and materials}

The datasets used and analysed during the current study are available from the corresponding author on reasonable request.

\section{Authors' contributions}

MB made substantial contributions to conception and design, acquisition of data as well as analysis and interpretation of data. AC made substantial contributions to conception and design. SH and DV guided the in vivo experiments. RP synthesized the analyzed agent. BMS, CB and WU revised the manuscript. All authors have read and approved the manuscript and take public responsibility for it.

\section{Competing interests}

Dr. Pfirrmann had indeed a scientific advising function at Geistlich Pharma $A G$, and was not participating on any profits of this firm. However, he left the firm and is no longer part of Geistlich Pharma. Therefore, no conflict of interest was disclosed.

\section{Consent for publication}

Not applicable.

\section{Ethics approval and consent to participate}

The local ethical committee approved collection of sample tissue from patients with PDAC as well as implantation and expansion of cancer tissue in xenograft mouse models. Written informed consent of all patients was documented according to the local ethics guidelines. The study was conducted according to the declaration of Helsinki. All procedures were performed according to a protocol approved by the ethics committee of the RuhrUniversity Bochum (permission no. 2392 3. amendment). All animal experiments were performed according to the guidelines of the local Animal Use and Care Committees (permission no. 84-02.04.2012.A395).

\section{Publisher's Note}

Springer Nature remains neutral with regard to jurisdictional claims in published maps and institutional affiliations.

\section{Author details}

${ }^{1}$ Division of Molecular and Clinical Research, St. Josef-Hospital, Ruhr-University Bochum, Bochum, Germany. ${ }^{2}$ Department of Molecular Gastrointestinal Oncology, Ruhr-University Bochum, Bochum, Germany. ${ }^{3}$ Geistlich Pharma AG, Wolhusen, Switzerland. ${ }^{4}$ Department of Internal Medicine, Knappschaftskrankenhaus, Ruhr-University Bochum, Bochum, Germany.

Received: 1 November 2016 Accepted: 17 March 2017

Published online: 24 March 2017

\section{References}

1. Ryan DP, Hong TS, Bardeesy N. Pancreatic Adenocarcinoma. N Engl J Med. 2014;371:1039-49.

2. Malvezzi M, Bertuccio P, Levi F, La Vecchia C, Negri E. European cancer mortality predictions for the year 2013. Ann Oncol. 2013;24:792-800.

3. Cancer Facts and Figures / American Cancer Society. 2015. http://old.cancer. org/acs/groups/content/@editorial/documents/document/acspc-044552.pdf.

4. Stewart BW, Wild CP. World Cancer Report. 2014. ISBN: 978-92-832-0443-5.

5. Burris HA, Moore MJ, Andersen J, Green MR, Rothenberg ML, Modiano MR, et al. Improvements in survival and clinical benefit with gemcitabine as firstline therapy for patients with advanced pancreas cancer: a randomized trial. J Clin Oncol. 1997;15:2403-13.

6. Ueno H, loka T, Ikeda M, Ohkawa S, Yanagimoto H, Boku N, et al. Randomized phase III study of gemcitabine plus S-1, S-1 alone, or gemcitabine alone in patients with locally advanced and metastatic pancreatic cancer in Japan and Taiwan: GEST study. J Clin Oncol. 2013;31:1640-8.

7. Conroy T, Desseigne F, Ychou M, Bouché O, Guimbaud R, Bécouarn Y, et al. FOLFIRINOX versus gemcitabine for metastatic pancreatic cancer. N Engl J Med. 2011:364:1817-25.

8. Von Hoff DD, Ervin T, Arena FP, Chiorean EG, Infante J, Moore M, et al. Increased survival in pancreatic cancer with nab-paclitaxel plus gemcitabine. N Engl J Med. 2013;369:1691-703.

9. Jurewitsch B, Lee T, Park J, Jeejeebhoy K. Taurolidine $2 \%$ as an antimicrobial lock solution for prevention of recurrent catheter-related bloodstream infections. JPEN J Parenter Enteral Nutr. 1998;22:242-4.

10. Jacobi CA, Ordemann J, Böhm B, Zieren HU, Sabat R, Müller JM. Inhibition of peritoneal tumor cell growth and implantation in laparoscopic surgery in a rat model. Am J Surg. 1997;174:359-63.

11. McCourt M, Wang JH, Sookhai S, Redmond HP. Taurolidine inhibits tumor cell growth in vitro and in vivo. Ann Surg Oncol. 2000;7:685-91.

12. Rodak R, Kubota $H$, Ishihara $H$, Eugster $H-P$, Könü D, Möhler $H$, et al. Induction of reactive oxygen intermediates-dependent programmed cell death in human malignant ex vivo glioma cells and inhibition of the vascular endothelial growth factor production by taurolidine. J Neurosurg. 2005;102:1055-68

13. Sun BS, Wang JH, Liu LL, Gong SL, Redmond HP. Taurolidine induces apoptosis of murine melanoma cells in vitro and in vivo by modulation of the BCl-2 family proteins. J Surg Oncol. 2007;96:241-8.

14. Aceto N, Bertino P, Barbone D, Tassi G, Manzo L, Porta C, et al. Taurolidine and oxidative stress: a rationale for local treatment of mesothelioma. Eur Respir J. 2009;34:1399-407.

15. Chromik AM, Daigeler A, Bulut D, Flier A, May C, Harati K, et al. Comparative analysis of cell death induction by Taurolidine in different malignant human cancer cell lines. J Exp Clin Cancer Res. 2010;29:21. 
16. Stendel R, Picht T, Schilling A, Heidenreich J, Loddenkemper C, Jänisch W, et al. Treatment of glioblastoma with intravenous taurolidine. First clinical experience. Anticancer Res. 2004;24:1143-7.

17. Braumann C, Gutt CN, Scheele J, Menenakos C, Willems W, Mueller JM, et al. Taurolidine reduces the tumor stimulating cytokine interleukin-1beta in patients with resectable gastrointestinal cancer: a multicentre prospective randomized trial. World J Surg Oncol. 2009;7:32.

18. Gong L, Greenberg HE, Perhach JL, Waldman SA, Kraft WK. The pharmacokinetics of taurolidine metabolites in healthy volunteers. J Clin Pharmacol. 2007:47:697-703.

19. Clauss K, Lück E, von Rymon Lipinski GW. Acetosulfam, a new sweetener. 1. Synthesis and properties (author's transl). Zeitschrift für Leb und -forsch. 1976;162:37-40

20. Jacobi CA, Sabat R, Ordemann J, Wenger F, Volk HD, Müller JM. Peritoneal instillation of taurolidine and heparin for preventing intraperitoneal tumor growth and trocar metastases in laparoscopic operations in the rat model. Langenbecks Arch für Chir. 1997;382:S31-6.

21. Jacobi CA, Peter FJ, Wenger FA, Ordemann J, Müller JM. New therapeutic strategies to avoid intra- and extraperitoneal metastases during laparoscopy: results of a tumor model in the rat. Dig Surg. 1999;16:393-9.

22. Stendel R, Scheurer L, Schlatterer K, Stalder U, Pfirrmann RW, Fiss I, et al. Pharmacokinetics of taurolidine following repeated intravenous infusions measured by HPLC-ESI-MS/MS of the derivatives taurultame and taurinamide in glioblastoma patients. Clin Pharmacokinet. 2007;46:513-24.

23. Gorman SP, McCafferty DF, Woolfson AD, Jones DS. Reduced adherence of micro-organisms to human mucosal epithelial cells following treatment with Taurolin, a novel antimicrobial agent. J Appl Bacteriol. 1987;62:315-20.

24. Bedrosian I, Sofia RD, Wolff SM, Dinarello CA. Taurolidine, an analogue of the amino acid taurine, suppresses interleukin 1 and tumor necrosis factor synthesis in human peripheral blood mononuclear cells. Cytokine. 1991;3:568-75.

25. Leithäuser ML, Rob PM, Sack K. Pentoxifylline, cyclosporine a and taurolidine inhibit endotoxin-stimulated tumor necrosis factor-alpha production in rat mesangial cell cultures. Exp Nephrol. 1997;5:100-4.

26. Stendel R, Biefer HRC, Dékány GM, Kubota H, Münz C, Wang S, et al. The antibacterial substance taurolidine exhibits anti-neoplastic action based on a mixed type of programmed cell death. Autophagy. 2009;5:194-210.

27. Vanden Berghe T, Vanlangenakker N, Parthoens E, Deckers W, Devos M, Festjens $\mathrm{N}$, et al. Necroptosis, necrosis and secondary necrosis converge on similar cellular disintegration features. Cell Death Differ. 2010;17:922-30.

28. Ouyang L, Shi Z, Zhao S, Wang F-T, Zhou T-T, Liu B, et al. Programmed cell death pathways in cancer: a review of apoptosis, autophagy and programmed necrosis. Cell Prolif. 2012;45:487-98.

29. Stendel R, Scheurer L, Stoltenburg-Didinger G, Brock M, Möhler H. Enhancement of Fas-ligand-mediated programmed cell death by taurolidine. Anticancer Res. 2003;23:2309-14.

30. Shrayer DP, Lukoff H, King T, Calabresi P. The effect of Taurolidine on adherent and floating subpopulations of melanoma cells. Anti-Cancer Drugs. 2003;14:295-303.

31. Nici L, Monfils B, Calabresi P. The effects of taurolidine, a novel antineoplastic agent, on human malignant mesothelioma. Clin Cancer Res. 2004;10:7655-61.

32. Möhler H, Pfirrmann RW, Frei K. Redox-directed cancer therapeutics: Taurolidine and Piperlongumine as broadly effective antineoplastic agents. Int J Oncol. 2014;45:1329-36.

33. Opitz I, Sigrist B, Hillinger S, Lardinois D, Stahel R, Weder W, et al. Taurolidine and povidone-iodine induce different types of cell death in malignant pleural mesothelioma. Lung Cancer. 2007;56:327-36.

34. Tait SWG, Ichim G, Green DR. Die another way-non-apoptotic mechanisms of cell death. J Cell Sci. 2014;127:2135-44.

35. Kroemer G, Martin SJ. Caspase-independent cell death. Nat Med. 2005;11:725-30.

36. Kim E-A, Jang J-H, Lee $\mathrm{Y}-\mathrm{H}$, Sung E-G, Song I-H, Kim J-Y, et al. Dioscin induces caspase-independent apoptosis through activation of apoptosisinducing factor in breast cancer cells. Apoptosis. 2014;19:1165-75.

37. Leon LJ, Pasupuleti N, Gorin F, Carraway KL. A cell-permeant amiloride derivative induces caspase-independent. AlF-mediated programmed necrotic death of breast cancer cells PLoS One. 2013;8:e63038.

38. Braumann C, Ordemann J, Kilian M, Wenger FA, Jacobi CA. Local and systemic chemotherapy with taurolidine and taurolidine/heparin in colon cancer-bearing rats undergoing laparotomy. Clin. Exp. Metastasis. 2003;20:387-94

39. Opitz I, van der Veen HC, Braumann C, Ablassmaier B, Führer K, Jacobi CA. The influence of adhesion prophylactic substances and taurolidine/heparin on local recurrence and intraperitoneal tumor growth after laparoscopicassisted bowel resection of colon carcinoma in a rat model. Surg Endosc. 2003;17:1098-104.

40. Bobrich E, Braumann C, Opitz I, Menenakos C, Kristiansen G, Jacobi CA. Influence of intraperitoneal application of taurolidine/heparin on expression of adhesion molecules and colon cancer in rats undergoing laparoscopy. J Surg Res. 2007;137:75-82.

41. Braumann C, Stuhldreier B, Bobrich E, Menenakos C, Rogalla S, Jacobi CA. High doses of taurolidine inhibit advanced intraperitoneal tumor growth in rats. J Surg Res. 2005;129:129-35.

42. Nestler G, Schulz HU, Schubert D, Krüger S, Lippert H, Pross M. Impact of taurolidine on the growth of CC531 coloncarcinoma cells in vitro and in a laparoscopic animal model in rats. Surg Endosc. 2005;19:280-4.

43. Raue W, Kilian M, Braumann C, Atanassow V, Makareinis A, Caldenas S, et al. Multimodal approach for treatment of peritoneal surface malignancies in a tumour-bearing rat model. Int J Color Dis. 2010;25:245-50.

44. Kilian M, Mautsch I, Braumann C, Schimke I, Guski H, Jacobi CA, et al. Effects of taurolidine and octreotide on tumor growth and lipid peroxidation after staging-laparoscopy in ductal pancreatic cancer. Prostaglandins Leukot Essent Fatty Acids. 2003;69:261-7.

45. Braumann C, Jacobi CA, Rogalla S, Menenakos C, Fuehrer K, Trefzer U, et al. The tumor suppressive reagent taurolidine inhibits growth of malignant melanoma-a mouse model. J Surg Res. 2007;143:372-8.

46. Braumann C, Ordemann J, Wildbrett P, Jacobi CA. Influence of intraperitoneal and systemic application of taurolidine and taurolidine/ heparin during laparoscopy on intraperitoneal and subcutaneous tumour growth in rats. Clin Exp Metastasis. 2000;18:547-52.

47. Da Costa ML, Redmond HP, Bouchier-Hayes DJ. Taurolidine improves survival by abrogating the accelerated development and proliferation of solid tumors and development of organ metastases from circulating tumor cells released following surgery. J Surg Res. 2001;101:111-9.

48. Darnowski JW, Goulette FA, Cousens LP, Chatterjee D, Calabresi P. Mechanistic and antineoplastic evaluation of taurolidine in the DU145 model of human prostate cancer. Cancer Chemother Pharmacol. 2004;54:249-58.

\section{Submit your next manuscript to BioMed Central and we will help you at every step:}

- We accept pre-submission inquiries

- Our selector tool helps you to find the most relevant journal

- We provide round the clock customer support

- Convenient online submission

- Thorough peer review

- Inclusion in PubMed and all major indexing services

- Maximum visibility for your research

Submit your manuscript at www.biomedcentral.com/submit
C) Biomed Central 